\title{
Hispanidad y Revolución: la vieja guardia del Modernismo ante la guerra civil española ${ }^{1}$
}

\section{Hispanidad and Revolution: Modernism's old school in the face of the Spanish Civil War}

\author{
NIALL BINNS \\ Universidad Complutense de Madrid \\ Correo electrónico: nbinns@filol.ucm.es
}

\begin{abstract}
¿Cómo reaccionaron las viejas glorias del modernismo ante la guerra civil española? Este artículo indaga en el posicionamiento político e ideológico de autores que fueron, en su momento, figuras importantes del movimiento modernista. En un primer instante, se analiza la actitud ante la guerra de dos de los grandes poetas del modernismo: Guillermo Valencia y Leopoldo Lugones. A continuación, se examina la reacción de tres exmodernistas hispanófilos: los novelistas Carlos Reyles y Enrique Larreta, y el peruano Felipe Sassone. Entre los antiguos modernistas que retenían en parte su espíritu revolucionario juvenil, se examinan las figuras de Manuel Ugarte, Alberto Ghiraldo, Alejandro Sux y Horacio Quiroga... Como colofón, se contempla el papel que tuvieron en el conflicto Manuel González Prada, José Martí y Rubén Darío, resucitados por sus herederos como partidarios, respectivamente, del anarquismo, de la República, y de Franco y la Hispanidad.
\end{abstract}

Palabras clave: Modernismo, guerra civil española

How did the old school of modernistas react to the Spanish Civil War? The article explores the political and ideological positioning of authors who were, in their heyday, important figures of the modernist movement. It focuses initially on the attitude towards the war of two of the movement's greatest poets, Guillermo Valencia and Leopoldo Lugones, before analysing the reaction of three hispanophiles: two novelists, Carlos Reyles and Enrique Larreta, and Peruvian Felipe Sassone. Among the ex-modernistas who retained part of the revolutionary spirit of their youth, the article centres on Manuel Ugarte, Alberto Ghiraldo, Alejandro Sux and Horacio Quiroga... A brief colophon examines the role in the conflict of Manuel González Prada, José Martí and Rubén Darío, resuscitated by their heirs as followers, respectively, of Anarchism, of the Republic, and of Franco and "la Hispanidad".

Key words: Modernism, Spanish Civil War

\footnotetext{
${ }^{1}$ Este trabajo forma parte del proyecto de investigación "El impacto de la guerra civil española en la vida intelectual de Hispanoamérica”, financiado actualmente por el Ministerio de Economía y Competitividad (FFI2015-65817-P).
} 
El centenario de la muerte de Rubén Darío ha invitado a repasar una vez más el legado del modernismo, volver a examinar no sólo la naturaleza transformadora de las propuestas del nicaragüense, su papel de "Libertador", sino también la pervivencia de lo que fue su labor de renovación, una labor -en palabras de Borges, proferidas en el centenario de su nacimiento- que "no ha cesado y no cesará". Darío lo había cambiado todo, había propulsado una alteración radical de las reglas de juego poéticas de la cual no existía vuelta atrás posible, ${ }^{2}$ pero era una liberación, desde luego, paradójica, porque lo cierto es que en 1967, al igual que en 2016, poco permanecía - poco permanece- de los vuelos ritmados y de esa ornamentación exquisita que tanto habían irritado al propio Borges en su juventud (Borges 1997: 126).

No cabe duda respecto a la naturaleza revolucionaria del modernismo en el campo de la literatura y sobre todo la poesía de lengua española, ${ }^{3}$ pero no se limitó a un cambio estrictamente estético. La crítica - partiendo de los estudios de Ángel Rama (1970), Rafael Gutiérrez Girardot (1983) y Álvaro Salvador (1986) - ya ha asumido que Darío y los suyos encarnaron en su imaginería y musicalidad deslumbrantes una oposición estética a los estragos materialistas del positivismo y la chatura espiritual de las urbes latinoamericanas de finales del siglo XIX. Esta oposición, ceñida a la palabra escrita, no llevaba necesariamente a que el escritor se encerrase en su torre de marfil, y no sorprende que varios de los modernistas dirigieran su espíritu inconformista no sólo a una transformación en los dominios del arte sino también hacia formas embrionarias del socialismo y sobre todo hacia el anarquismo, ideologías que compartían -desde otro punto de vista- la misma hostilidad ante los reyes burgueses y el joven capitalismo americano. ${ }^{4}$ Este cruce de militancias estéticas, éticas y políticas,

2 "Cuando un poeta como Darío ha pasado por una literatura, todo en ella cambia. [...] Todo lo renovó Darío: la materia, el vocabulario, la métrica, la magia peculiar de ciertas palabras, la sensibilidad del poeta y sus lectores. Su labor no ha cesado y no cesará; quienes alguna vez lo combatimos comprendemos hoy que lo continuamos. Lo podemos llamar el Libertador" (Borges 1968: 13).

${ }^{3}$ Según Max Henríquez Ureña: "Las dos últimas décadas del siglo xix señalaron el advenimiento de una revolución literaria que abarcó en su órbita a todos los pueblos de habla española en el Nuevo Mundo y que, posteriormente, se extendió a España. El nombre que se aplicó a ese movimiento fue el de modernismo" (1962: 11); y en palabras de José Emilio Pacheco: "Al comienzo del imperio español la revolución poética de Garcilaso de la Vega abre las puertas al lenguaje del Renacimiento. En esa época se escriben los primeros poemas castellanos de América. Cuando el imperio llega a su fin en Cuba y Puerto Rico, la revolución poética consumada -si no iniciada- por Rubén Darío abre las puertas al lenguaje del mundo moderno. Entonces simbolismo y parnasismo eran el dolce stil nuovo: los medios para crear una poesía nunca antes escrita en español” (1999: xii).

\footnotetext{
${ }^{4}$ Según Viñas: "Aparentemente contrapuestos en su estilo, preferencias, protagonistas y escenarios, los escritores rubénianos y los intelectuales anarquistas del 1900 comparten sin embargo una ancha franja de coincidencias. El eje posible de esa superposición aparece por lo general en el espacio de la bohemia: su exaltación del individualismo más tenso y algunos componentes que prolongan lo que podría llamarse la izquierda liberal de esa circunstancia histórica van corroborando esa zona marginal que se densifica en ciertas preferencias de su 'biblioteca mental': Verlaine, Tolstoi, el Ibsen más crítico de la sociedad de su tiempo, Mirbeau y algunas figuras más borrosas del decadentismo finisecular. Incluso, coinciden en la celebración del malditismo literario en tanto implique homenajes a una práctica literaria distanciada de un 'burgués' evaluado fundamentalmente por sus rasgos estéticos" (Viñas 2004: 133-134).
} 
nacido acaso en 1897, en Bogotá y a la vez en Buenos Aires, y encapsulado en la noción de bohemia revolucionaria, conllevó contradicciones pero no siempre renuncias: "Ni los ácratas prescindirán de las fábulas, moralejas y parábolas que impregnan su literatura con un discurso machacón, ni la que Borges llamara la tribu de Rubén se resistirá a ese catálogo exótico que se realimenta en las exposiciones universales que son la contracara del internacionalismo de los desposeídos voceado por los heraldos de la resistencia” (Croce 2001: 531).

"Ir avanzando en los caminos de la vida y mantenerse como revolucionario, en una sociedad burguesa, es difícil”, afirmaba Salvador Allende en un texto -parte de un discurso que pronunció en México de 1972- que he incorporado como epígrafe a uno de los apartados de este trabajo (Amorós 2008: 42). Difícil, pero no imposible. Así lo veremos, en algunos casos, al sacar a los modernistas de su hábitat finisecular o de comienzos del xx para proyectarlos -iconoclastas de antańo, sobrevivientes de una estética periclitada- al año 1936 y a unas circunstancias culturales y socioeconómicas dramáticamente distintas. El debate sobre España, tan nutrido en los años gloriosos de su juventud -entre el furor parnasiano, el "galicismo mental" y los "mil cachorros sueltos del León Espańol"-, resucitaría ahora en torno al mapa de una República Española trágicamente frustrada en su vocación reformista y escindida por el extremismo revolucionario. ${ }^{5}$

\footnotetext{
${ }^{5}$ Quizá convenga recordar aquí las dificultades que tuvieron los coetáneos españoles del modernismo -sus viejos compañeros de la generación del 98, algunos de ellos, como Azorín y Ramiro de Maeztu, de pasado anarquistaa la hora de adaptarse al radicalismo ideológico de los años de la guerra civil. Miguel de Unamuno se adhirió desde el inicio a la sublevación militar para luego, a partir del 12 de octubre de 1936 ("venceréis, pero no convenceréis"), plegarse a un amargo silencio que lo acompañaría hasta su muerte a finales de ese año; Ramiro de Maeztu -adalid de la Hispanidad y principal ideólogo, junto a José Antonio Primo de Rivera, del bando franquista- fue fusilado a manos de milicianos republicanos a finales de octubre de 1936. Otros intelectuales de su generación -entre ellos los tres "padres" de la República: José Ortega y Gasset, Gregorio Marañón y Ramón Pérez de Ayala- firmaron en el diario madrileńo $A B C$ un manifiesto de adhesión tanto al gobierno de la República como al pueblo "que con heroísmo ejemplar lucha por sus libertades" ( $A B C$ 1936: 30). El gobierno republicano lo celebró como prueba de la lealtad casi unánime de sus intelectuales, pero antes de que terminara 1936 esos tres "padres", al igual que otros firmantes del manifiesto -Ramón Menéndez Pidal y Antonio Marichalar-, habían dejado España para instalarse en París. Desde Francia observarían a partir de entonces la guerra, distanciándose de la República y preparándose lentamente -con un silencio cada vez más matizado en su actitud hacia Franco- para un eventual regreso a Espańa. Habían aprendido, todos ellos, el drama de "ser liberal en un mundo que no aceptaba los liberalismos" (Trapiello 2010: 97). A esta "deserción" de los intelectuales liberales, de los antiguos abanderados de la República -a los que habría que ańadir a Pío Baroja y Azorín, y en los que destacaban como excepciones luminosas en su lealtad las figuras de Antonio Machado y de Juan Ramón Jiménez, a pesar de que este se ausentara en cuanto pudo de Madrid-, Jordi Gracia la ha denominado la "capitulación de los maestros". Eran "hombres cansados, cerca de la vejez o en la vejez misma", atrapados en una especie de "espiral incontrolada" que los arrastraba hacia el fascismo y el franquismo: "La espiral hacia la capitulación tiene nombre: es la colaboración del liberal español con el fascismo y su institucionalización en forma de Estado franquista. La palabra 'colaboración' es gruesa y está marcada, así que puede rebajarle el lector por su cuenta, o encontrar un sinónimo más convincente para nombrar el hecho central: aspiran a la victoria de Franco durante la guerra y aspiran también a regresar lo antes posible, cuando termine la guerra, los mismos nombres que hacia 1936, nadie hubiera discutido como maestros liberales y, como tales, incompatibles con un sistema totalitario" (Gracia 2004: 46-47).
} 


\section{LA VUELTA AL ORDEN}

Muchos jóvenes heréticos acaban convirtiéndose en viejos fanáticos, y muchos jóvenes revolucionarios acaban como viejos reaccionarios.

Albert Einstein

Seguían en pie, en 1936, dos de las viejas glorias del modernismo, poetas que en un lejanísimo pasado de euforia estética y libertaria habían coqueteado con la revolución pero que estaban, desde hacía tiempo, convertidos en dirigentes influyentes de los sectores más derechistas de la política de sus países respectivos. Me refiero a Guillermo Valencia (18731943) y a Leopoldo Lugones (1874-1938).

Al primero de ellos se debe "Anarkos", un extenso poema, escrito en 1897 después de lecturas férvidas de Nietzsche y Bakunin, que retrataba con altisonante vuelo épico la sordidez de un mundo injusto pero al borde de la rebelión, enfocando sucesivamente a un "mísero can, hermano / de los parias", a los mineros - "valientes campeones / que vertieron sus lágrimas / entre los socavones"- y a una "turba de profetas" - la "desventurada tribu" de pintores, escultores, músicos y poetas-, todos ellos soliviantados por una violencia libertaria traída desde Oriente por los "hijos de Anarkos":

¿Por qué se abren sus ojos

desmesuradamente?

¡Ah! si es que apunta con fulgores rojos

el astro de la sangre por Oriente.

Bajo el odio del viento y de la lluvia

por la rígida estepa se adelantan

los domadores de la Bestia rubia:

ya los perros sarnosos

se tornaron chacales. De ira ciego

el minero de ayer se precipita

sobre los tronos. Un airado fuego

entre sus manos trémulas palpita, y sorda a la niñez, al llanto, al ruego,

¡ruge la tempestad de dinamita!

¡Son los hijos de Anarkos! Su mirada, con reverberaciones de locura,

evoca ruinas y predice males:

parecen tigres de la Selva oscura

con nostalgias de víctima y juncales. 
El furioso caer de sus piquetas

en trizas torna la vetusta arcada

que erigieron al Bien nuestros mayores;

y por la red de las enormes grietas

va filtrando, con tintes de alborada,

un sol de juventud sus resplandores (Valencia 1955: 136).

"Anarkos" llegó a ser -en palabras de David Viñas- "tan popular en su momento como El tren expreso de Campoamor o 'las golondrinas' de Bécquer en otra etapa histórica”, consiguiendo, "al apelar a la serie de recursos del orador libertario, insólitas adhesiones masivas" (Viñas 2004: 120). Ángel J. Cappelletti cita estas palabras de Viñas pero recuerda que en la obra de Valencia el poema es una excepción, y que en la mayoría de sus textos más célebres "no sólo no asoma para nada la genealogía libertaria de su musa sino más bien su condición de brillante huésped de un patriciado que tolera sus exotismos ideológicos":

Sus poesías están dedicadas a políticos, hacendados y monseñores. Y ¿cómo podría haber hecho otra cosa quien durante casi toda su vida fue diplomático o funcionario y dos veces candidato a la presidencia de la república? Anarkos no es más que un ejercicio de retórica a la moda del momento (Cappelletti 1990: CxLvIII-CXLIX).

En el verano de 1936, el poeta y ex-candidato conservador a la presidencia de Colombia vivía en Popayán, tenía ya 62 años y era conocido popularmente como el "maestro Valencia". Seguía siendo una figura política importante en su país y desde las páginas del semanario Claridad, dirigido por su hijo Guillermo León Valencia, se defendía ante sus rivales del diario conservador de Bogotá El Siglo, que habían trocado ese sobrenombre respetuoso por lo que él consideraba la "metáfora inadecuada" de "Júpiter tonante" (Valencia 1936a: 3), o ante los jóvenes irreverentes de un semanario enemigo de Popayán, Orientación Liberal, que cometieron la osadía de llamarlo "versificador latifundista" y "Júpiter feudal" de las letras colombianas (1936b: 3-4). El viejo poeta se paseaba libremente por las páginas de Claridad, firmando editoriales y artículos con las iniciales "G.V.", y mostrando una sintonía ideológica más que evidente con su hijo, que firmaba a su vez como "G.L.V.". Los editoriales sin firma del semanario pueden atribuirse a ambos pero llevan a veces alusiones que remiten irremediablemente al poeta. Así, cuando en una misma página encontramos el artículo "Asesinatos en España", traducido del francés por "G.V." y comentado al lado en el editorial sin firma "Fúnebre lista", parece más que probable que este sea del padre y no del hijo: "Qué laya de Saturno es este Frente popular que así devora a sus propios hijos?", preguntaba, para pedir a continuación que "Dios permita que muy pronto el clarín anunciador de la definitiva victoria lleve hasta aquellos mártires la vengadora voz de su España reconquistada” (Claridad 1936: 3).

En un editorial del año siguiente, "G.V." lamentó la muerte del capitán Luis Crespo Guzmán, un "héroe auténtico" e "hijo de Colombia" y de Popayán que se había alistado en la Legión extranjera y acababa de morir luchando en el País Vasco a favor de Franco contra 
"la barbarie asiática que al cabo de quince siglos vuelve a lanzar sus hordas contra la Europa occidental" (Valencia 1937: 3). Valencia no volvió a escribir en Claridad sobre la guerra española hasta el final del conflicto. Estuvo, mientras tanto, gravemente enfermo, y tuvo que ser intervenido quirúrgicamente en la ciudad neoyorquina de Rochester a comienzos de enero de 1939. Cuando llegaron a Colombia las noticias sobre la agonía definitiva de la República Española, el poeta estaba ya de regreso en Popayán y en una loa de tono encendido, "Arriba España!", celebró al general Franco como un "héroe máximo" que había sabido luchar contra "factores de una intensidad al parecer incontrastable" -el poderío y dinero del gobierno republicano, una ferocidad asesina "de que no hay ejemplo en la historia", el apoyo de las grandes potencias democráticas y la confluencia de "falanges rojas" desde dentro y fuera de Europa-, convirtiéndose así en "el nuevo Cid de todas las Españas, de la peninsular y las ultramarinas": "Admiramos a Franco, glorificamos a Franco, amamos a Franco" -exclamaba Valencia-, "porque venciendo en el solar de Hispania al oso siberiano de las garras sangrientas, lo dejó vencido también para las Repúblicas indoibéricas de este continente" (Valencia 1939: 3).

Este texto fue incluido en una amplia encuesta publicada por el diario conservador de Bogotá con el título "El pensamiento colombiano y el triunfo del Generalísimo Franco" (El Siglo 1939: 13), y suscitó una respuesta inmediata desde la página editorial de otro diario bogotano, El Liberal. Según este, Valencia había mostrado -con su contestación a la encuesta- ser un "consumado artífice de la hipérbole", practicando en ella un "tránsito continuo" de la poesía a la política y una "gongórica oscuridad en el concepto" en su celebración de un militar responsable por la muerte no sólo de soldados leales, sino también de mujeres y niños; ejemplificaba lo dicho explicando las metáforas del poeta: "En materia de bombardeos a las ciudades abiertas, no hay quien supere al general Franco, porque eso de 'las águilas de acero', tan sutil, tan nuevo y original, quiere decir 'aviones'; lo de 'explosivos destructores', significa 'bombas', y 'flechas de destino' debe traducirse por el lector despistado como 'balas de ametralladoras"' (El Liberal 1939: 5).

Valencia, que era incapaz de dejar una ofensa sin respuesta, contraatacó desde un editorial sin firma de Claridad, recordando que desde el inicio del conflicto "formamos resueltamente en el campo franquista, por razones obvias. Tradicionalistas hasta la médula de los huesos, todo cuanto tienda a mantener las basas de una sociedad civilizada llama nuestro fervor irresistiblemente". Con una alusión al asesinato de siete religiosos colombianos, perpetrado en Barcelona por milicianos anarquistas en agosto de 1936, declaraba que ese apoyo inicial se había inflamado más aún tras la muerte de "nuestros imbeles compatriotas" . Por ello, se sublevaba ante las acusaciones a Franco formuladas por individuos hipócritas que se complacían, en cambio, con los "asesinatos colectivos más abominables" cometidos jamás en la historia de la humanidad. De ahí la pregunta de Valencia: “¿Acaso los stalinófilos de El Liberal no se solidarizaron, sin hacer distingos de ningún género, con los antropófagos

\footnotetext{
${ }^{6}$ Estos religiosos, pertenecientes a la Orden de los Hermanos Hospitalarios de San Juan de Dios, fueron asesinados mientras procuraban escaparse de España, el 8 de agosto de 1936 (Hernández García 2006: 209-228).
} 
de la península? ¿La aviación marxista de España arrojaba flores sobre las ciudades que ocupaba el contrario?". En esas circunstancias, no había motivo ninguno para retractarse de lo dicho; al contrario, si algo le habían enseñado cuatro años de "República liberal" en Colombia, era que "si algo debemos lamentar es que no surja entre nosotros algún General Franco" (Claridad 1939: 3).

Al igual que Valencia, Lugones se había estrenado en el modernismo como anarquista, aunque participara después con la pasión de un pionero en el nacimiento del socialismo en Argentina. En el periódico bonaerense El Tiempo, el 12 de mayo de 1896, Rubén Darío, que acababa de conocerlo, le dedicó un breve artículo titulado precisamente "Un poeta socialista. Leopoldo Lugones", en el que afirmaba que el joven argentino "es, ante todo, un revolucionario; y un revolucionario completamente consciente. Él sabe por qué sigue los pabellones nuevos" (Mapes 1938: 103). Fundador del Centro Socialista Obrero Internacional en San Francisco, Córdoba, en 1895, Lugones viajó poco después a Buenos Aires y asistió como delegado cordobés a la fundación del Partido Socialista Argentino en junio del año siguiente, aunque no tardó en distanciarse de la línea ortodoxa y, a su juicio, insuficientemente revolucionaria de Juan B. Justo. ${ }^{8}$ En su primer poemario, Las montañas del oro, publicado en el mismo año en que Valencia escribió "Anarkos", Lugones procuró fundir su socialismo con la emergente estética modernista partiendo de la imagen inicial de una masa inquieta que se alzaba de las "hondas grutas" y avanzaba hacia la luz - "Es una gran columna de silencio i de ideas / En marcha” (Lugones 1897: 9-10)-, mientras que el poeta, una figura luminosa flanqueada por Dios y con el pecho dorado por el sol, "apostrofa con su clarín sonoro / A la columna en marcha” (11). Heredera de Hugo, Dante, Whitman y Homero, esa figura exaltada observa desde las alturas el avance de la masa, y es celebrada como "uno de esos enjendros del prodigio", de esos "armoniosos doctores del Espíritu Santo", alguien al que "tan de cerca le ha hablado Dios, que él habla lo mismo" (14-15).

Como había dicho Darío, Lugones era ante todo un revolucionario, y después de abandonar el socialismo -por considerarlo excesivamente moderado-, con el mismo ímpetu se hizo liberal y antiparlamentario y se convirtió a continuación en el primer escritor fascista de las Américas al anunciar en 1924, cuando acudió como representante del gobierno radical

\footnotetext{
${ }^{7}$ Valencia se refiere a los cuatro años de gobierno de Alfonso López Pumarejo, que llegó al poder el 7 de agosto de 1934 y fue sucedido, en 1938, por un presidente también liberal, pero notoriamente menos izquierdista: Eduardo Santos Montejo, tío abuelo del actual presidente de Colombia Juan Manuel Santos Calderón.

${ }^{8}$ El alejamiento de Lugones de la ortodoxia socialista surgió en parte de las críticas que recibió por celebrar la "aristocracia de sangre" de Luis de Saboya, un príncipe italiano que visitaba Buenos Aires, pero se consolidó como tendencia doctrinal en el grupo de izquierda que el poeta conformó, junto con Augusto Kuhn y José Ingenieros, y que criticó duramente -desde las páginas del "periódico socialista revolucionario" La Montaña- la ideología pequeño-burguesa de Justo. Así lo señala Javier Franzé, que en su artículo "Lugones, 1897: socialismo y modernismo" recuerda que a finales del siglo xIX socialismo y modernismo eran "dos modos de colocarse críticamente ante ese mundo nuevo del que son hijos", y retrata al poeta cordobés como una figura que encarnaba -de manera fallida, mediante una "apolitización" del socialismo- "el esfuerzo por ligar ambas problemáticas" (Franzé 1997: 63-64, 69-70).
} 
de Marcelo T. Alvear a los festejos del centenario de la Batalla de Ayacucho, su fe en el Ejército como la "última aristocracia" y como "la última posibilidad de organización jerárquica que nos resta entre la disolución demagógica”. Así lo encapsulaba, en palabras que se hicieron célebres: "Ha sonado otra vez, para bien del mundo, la hora de la espada" (Lugones 1931: 17-18).?

Lugones fue -junto con Carlos Ibarguren- el intelectual más cercano al general José Félix Uriburu, dictador después del golpe de estado del 6 de septiembre de 1930, y al año siguiente reunió en la editorial del Círculo Militar una colección de artículos bajo el título $\mathrm{La}$ patria fuerte. En 1933, redactó el programa de "Guardia Argentina”, una efímera confederación de grupos nacionalistas, pero para los jóvenes de la época, que se nutrían de las enseñanzas de Ramiro de Maeztu y los ideólogos del nazismo, Lugones era un hombre del pasado. No era el jefe que buscaban, y el sucesor de Uriburu en la presidencia, el general Agustín Pedro Justo, ignoró por completo al poeta, cuyo suicidio del 18 de febrero de 1938 "simbolizó el fracaso y la desilusión de las ideas destructivas que él representaba” (Rock 1993: 110-111).

Desde el abatimiento de sus últimos años, y a pesar de su supuesta conversión al catolicismo -que podría haberlo alineado con la "cruzada" de Franco-, Lugones no quiso escribir sobre la guerra española. Ese silencio no pasó inadvertido. Álvaro Yunque lo señalaba: "Ayer, como hoy, los poetas de verdad no estaban con la tiranía. ¿Quiénes cantan a la España leal?: Antonio Machado. ¿Y a Franco?... Ni Lugones se ha atrevido, todavía" (1937: 9). No fue, sin embargo, una cuestión de atrevimiento. Un artículo anónimo, publicado en el diario conservador de Córdoba Los Principios con el título "La revolución española divide a los escritores argentinos", aludió a los esfuerzos de otros nacionalistas -Manuel Gálvez, Ramón Doll y Ernesto Palacio- por constituir un movimiento "de carácter social-cristiano, más que político" para protestar contra "los actos vandálicos realizados por las turbas" en España. Cuando le propusieron la idea a Lugones, obtuvieron "una cortés pero rotunda negativa. Expresó el señor Lugones que según su criterio, los escritores argentinos no tenían por qué intervenir en un conflicto interno de una nación extranjera. Con ello se cerraban el camino para protestar o negarse a admitir, en el futuro, la injerencia de otros países en las cosas nuestras" (12 de agosto de 1936: 7).

A la luz de esta negativa de Lugones, consecuente a fin de cuentas con su ideario nacionalista, podríamos decir que la "contribución" más notoria del poeta a la guerra de España fue su hijo, Leopoldo "Polo" Lugones, que llevaba tiempo mostrándose consecuente también, aunque de otro modo, con las enseńanzas paternas. Nombrado comisario inspector por el general Uriburu, había establecido en la Penitenciaría Nacional de la calle Las Heras, en Buenos Aires, una sala de interrogatorios donde sistematizó por primera vez como método de tortura el uso de la picana eléctrica y donde inventó el método del "tacho": la sumersión del preso en un cubo lleno de excrementos. En esos años, fue ascendido a jefe de Orden Político de la policía de Buenos Aires y hacia finales de la guerra española, cuando

\footnotetext{
${ }^{9}$ Revolucionario y pionero como siempre, Lugones, en palabras de Federico Finchelstein, "puede ser presentado como el padre intelectual del fascismo argentino. Aunque, en términos ideológicos y culturales, también lo había sido previamente del liberalismo y el socialismo argentinos" (2008: 31).
} 
comenzaban a llegar noticias e imágenes del éxodo republicano hacia Francia, dirigió una carta abierta -que saldría publicada en el diario profranquista y profascista Crisolal representante de Franco en Argentina, el diplomático Juan Pablo de Lojendio. "Polo" Lugones se explayó en ella sobre los "desmanes" perpetrados en España por "las hordas rojas", celebró la "cruzada triunfal del General Franco", y suplicó a Lojendio que impidiera la llegada a su país de exiliados republicanos:

Dios quiera -como usted bien lo dice- que jamás pisen suelo argentino esos trabajadores díscolos embrutecidos por la prédica de Moscú; que tampoco vengan por acá maestros que ya ni siquiera españoles ni nada son, pues optaron por el internacionalismo irresponsable, tan abyecto que comienza renegando de la Patria y concluye abominando de la madre para definir así, por antonomasia, a más de un ídolo rojo venido al mundo al azar de cualquier aventura de zaguán... Y sobre todo, señor, que no aparezcan en tierra de San Martín los intelectuales de izquierda autores directos del tétrico panorama de España, mucho más culpables de la traición a su país que tal o cual dinamitero enloquecido por el odio aprendido en esa literatura malvada (cit. por Binns 2012b: 470).

\section{HISPANÓFILOS Y FRANQUISTAS}

Tened cuidado. ;Vive la América española!, hay mil cachorros sueltos del León Español.

Rubén Darío

Tal vez los dos grandes hitos hispanófilos del modernismo -junto a un puñado de poemas de Cantos de vida y esperanza- sean La gloria de Don Ramiro (1908) y El embrujo de Sevilla (1922), las novelas respectivas del argentino Enrique Larreta (1873-1961) y del uruguayo Carlos Reyles (1868-1938). Ambos se vieron involucrados en tensos debates en torno a la guerra civil a raíz de la visita al Cono Sur, en 1937, de Gregorio Marańón. Durante los primeros meses del conflicto, desde círculos simpatizantes de la República Española, el científico había sido celebrado como paradigma de la lealtad. Sus proclamas radiofónicas se consideraban una prueba irrefutable. A comienzos de 1937, sin embargo, ya instalado en París, había cambiado de discurso; reconoció públicamente el error que había cometido al apoyar un gobierno de Frente Popular que estaba ahora en manos del comunismo. Para los intelectuales progresistas del Río de la Plata, Marañón encarnaría a partir de entonces la figura del traidor, y como tal lo recibieron cuando viajó por el Cono Sur y Brasil, invitado por el Ministerio de Salud Pública de Uruguay, en marzo y abril de $1937 .{ }^{10}$

\footnotetext{
${ }^{10}$ Sobre la visita del científico al Uruguay, véase mi artículo “¿El 'sabio' o el 'traidor’? Gregorio Marañón entre los intelectuales de Uruguay (Montevideo, 1937)” (Binns 2011).
} 
En la tarde del 15 de marzo, se organizó en Montevideo un protestado acto de homenaje al recién llegado Marañón, que fue arropado con discursos de bienvenida por parte del ministro Juan César Mussio Fournier, un viejo amigo que había trabajado con él en Madrid, y de Carlos Reyles. Este no contaba con un pasado ni de veleidades anarquistas como Valencia, ni de militancia revolucionaria en el socialismo como Lugones. Hacendado de una gran fortuna, era el fundador de la ultraconservadora Federación Rural y un admirador de Charles Maurras, de Mussolini, y del dictador español Miguel Primo de Rivera, que en los años veinte había tenido la gentileza de nombrarlo "hijo adoptivo e ilustre de Sevilla” (Binns 2016: 620). En la década de los treinta, el caudal de sus riquezas se había secado pero era el intelectual más prestigioso alineado con la dictadura de Terra, a pesar de que sus logros literarios de antaño empezaran a sufrir un desgaste que se ha mantenido hasta hoy.

En su discurso de bienvenida al ilustre visitante, que el diario presidencial El Pueblo titularía al día siguiente "La voz extinguida de Unamuno renace en Marañón", Reyles renunció a enumerar el conocidísimo historial de un científico que "nació sabio, historiador, psicólogo, literato", que "posee sensibilidad científica, histórica, psicológica, literaria", y que combinaba el saber acumulado con "el don y la gracia", y con una faceta creadora que daba una personalidad inconfundible a sus escritos. Lo que más destacaría Reyles de Marañón era su atrevimiento a la hora de romper con "los ídolos que él mismo adoró", en nombre de la verdad y a sabiendas de que ni la juventud, siempre generosa pero "intoxicada" con ideas marxistas, ni el pueblo se lo perdonaría nunca. Porque "el morbo moscovita no perdona. Una vez ingerido destruye, mata mientras la mente enturbiada se llena de paradisíacas visiones". Por ello, Reyles hizo hincapié en el parentesco de Marañón con Miguel de Unamuno, "el español más grande y más español de España", que se había sentido obligado a lanzar "sus anatemas a los cuatro vientos contra Moscú, contra las invasiones de los bárbaros, contra los que trocaron la república, que el pueblo engañado creía defender, por el despotismo rojo, el más cruel y estúpido de todos los despotismos", y que había muerto de dolor, "del dolor de su España vendida y crucificada". Siguiendo la estela de Unamuno, "otro espańol republicano de gran volumen representativo, el doctor Marañón, flagela ahora los desmanes, los crímenes y la barbarie del Frente Popular bolcheviquizado. La voz extinguida de Unamuno renace en el enfervorizado pecho del doctor Marañón" (cit. por Binns 2016: 622-623).

A finales de marzo Marañón se trasladó a Argentina, donde emprendió una vertiginosa sucesión de conferencias, celebradas entre protestas, la más polémica de las cuales, titulada "Libertad y soledad", fue organizada por la directora de la revista Sur, Victoria Ocampo, que recibió viscerales críticas, entre ellas la de José Bergamín, por la "equivocada y equívoca protección" a un intelectual que se había mostrado "enemigo nuestro. Enemigo del pueblo español. Enemigo de España” (cit. por Binns 2012b: 70-73). La revista El Hogar, en su edición del 9 de abril, mostraría a Marañón en un banquete organizado por el PEN Club, rodeado de muchos de los intelectuales nacionalistas y simpatizantes de Franco más destacados del país, entre ellos Carlos Ibarguren y Manuel Gálvez. No figura en las imágenes de esas páginas Enrique Larreta, uno de los pocos intelectuales argentinos -al igual que 
Lugones- capaces de evitar todo posicionamiento público ante la guerra de Espańa. No iba a renunciar, sin embargo, a recibir a Marañón, y en medio del griterío y los abucheos este pudo gozar del que fue, quizá, el único remanso de paz de su viaje cuando Larreta lo invitó a pasar el día en su casa de Belgrano -hoy el Museo de Arte Español Enrique Larreta- y a pasear en su yate el "Buen Aire" por El Tigre y el Delta del Paraná. Los acompañó, entre otros, Alberto Casal Castel, editor de El Hogar, que publicaría en su página editorial del 16 de abril la crónica "Diez horas con Gregorio Marañón”, y en el mismo número mostró once fotografías del paseo, durante el cual "las bellezas del Tigre desfilaron ante los ojos de los excursionistas, quienes, en su condición de poetas, historiadores y ensayistas, supieron aderezarlas debidamente para que el doctor Marańón tuviera, a la vez que la sensación de su hermosura, el conocimiento exacto de su significación histórica y de su realidad geográfica" (El Hogar 1937: 40). 


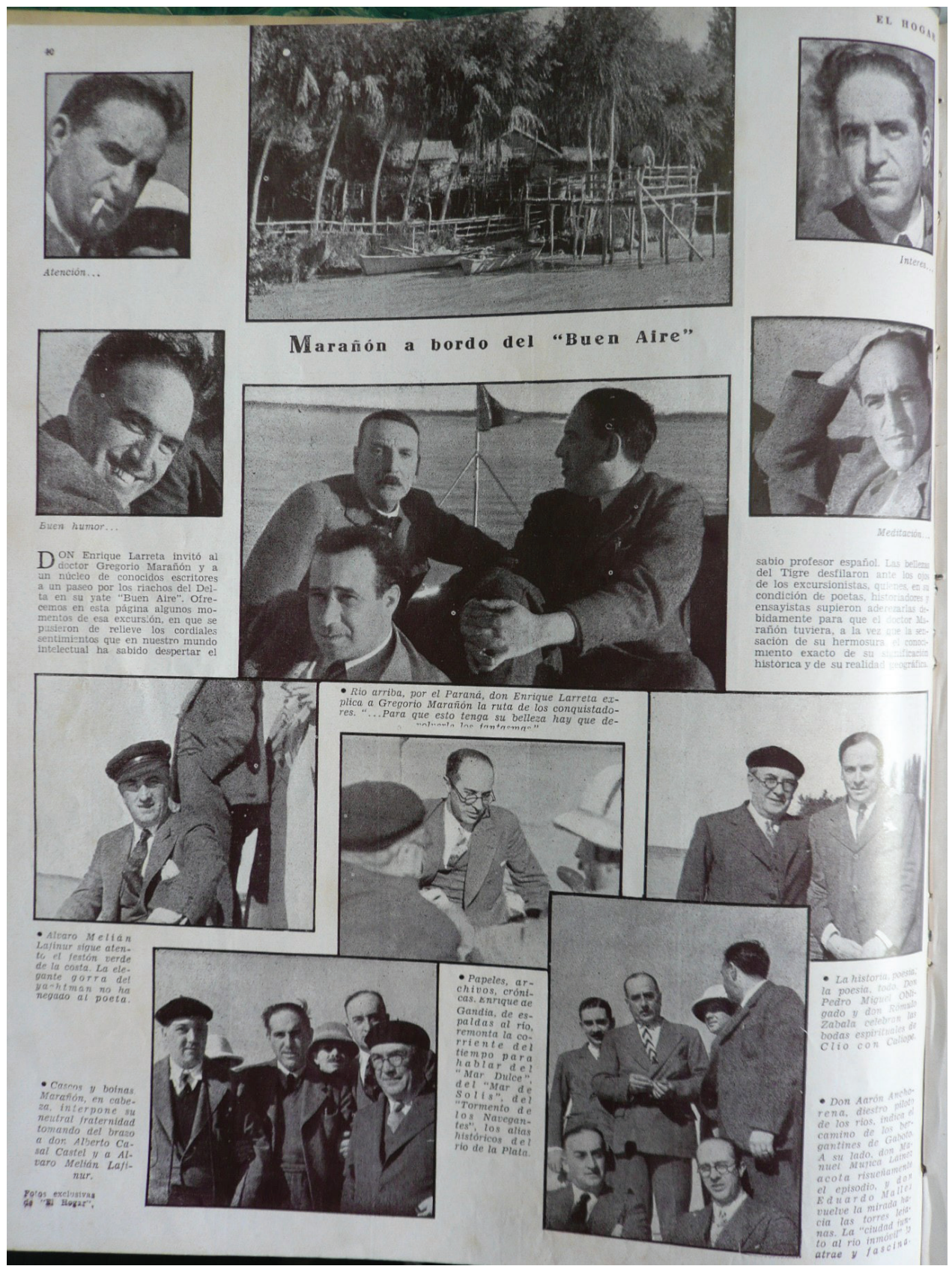

Fig. 1. Revista El Hogar, 16 abril 1937, p. 40. 
El novelista, poeta, ensayista y sobre todo dramaturgo peruano Felipe Sassone (1886-1959), que residía en España desde los veinte años de edad, se convertiría, después de escaparse de Madrid en el verano de 1936, en una de las voces más autorizadas sobre el conflicto en el Perú, prodigándose en conferencias, artículos, recitales radiofónicos y entrevistas (Muñoz Carrasco 2013: 457). Sus vínculos con el modernismo habían sido proclamados fastuosamente en La canción del bohemio y otros poemas, un libro publicado un ańo después de la muerte de Rubén Darío, dedicado al "dulce, hondo y altísimo poeta" y "suave maestro inolvidable" -al que suplicaba que trajera "un rayo de piadosa luz hasta la pobre oscuridad de mis rimas"-, prologado con la nota necrológica que Sassone escribió sobre el nicaragüense, recordando las largas noches de bohemia que habían compartido, ${ }^{11}$ y decorado con varios poemas de un tono netamente dariano - "Un fauno espiaba", "Versallesco", "Neurastenia sensual", "Una canción de Pierrot"- y con otro, "Rubén Darío", que era un homenaje al maestro, amigo y "poeta egregio, poeta sin segundo, / que dio a la vieja métrica su nueva orientación" (Sassone 1917: 59). "La canción del bohemio" inaugural concentra todos los tópicos de ensueño, loco idealismo, arte por el arte, "sonora rebeldía", oposición a las "formas anticuadas" y a las "tiranas academias", en lo que el cantor bohemio reconoce, con orgullo, como "la ilógica doctrina de mi credo modernista" (24).

Con el paso de los años, la bohemia de Sassone se iría disciplinando y en 1923 entró como redactor en el diario conservador $A B C$. Allí siguió trabajando durante los años de la República, como recordaría en España, madre nuestra, un libro de "notas autobiográficas" que publicó al regresar a Madrid en 1939 y que se centraron sobre todo en la época republicana y las primeras semanas de la guerra civil. Desde la atalaya de su periódico había vivido con angustia el "horroroso bienio de la azaña sin hache", en el que "cada día duraba como un siglo, y no era de progreso, sino de atraso y de barbarie" (Sassone 1939: 72), ${ }^{12}$ y a su vuelta de un viaje largo al Perú en 1935, se dejó cautivar por la "simpatía irresistible" y el "soberbio valor personal" del dirigente falangista José Antonio Primo de Rivera, y seducir tanto por las "admoniciones" de Ramiro de Maeztu como por los libros y folletos que le pasaban sus compañeros de redacción Eugenio Montes y Rafael Sánchez Mazas. Así, se fue "convirtiendo poco a poco a la causa del duce italiano y del joven caudillo español" y terminó, a pesar de ser un "individualista furibundo", adhiriéndose a Falange Española (162-163). Sassone fue testigo en Madrid del fracaso de la "santa rebelión" (184)

\footnotetext{
11 "Más de una vez, en el París galante o en el Buenos Aires cosmopolita, durante el alba que seguía a las noches de sensualidad, el pobre poeta, brumoso de spleen y luminoso de aurora, ebrio del amor de las peripatéticas y de whisky, de ajenjo y de champańa, abatíase en un diván profundo como su pena, y me hablaba de la muerte"; "Ya no le veré más a la puerta de las tabernas parisinas, esparcir su tedio bajo la fronda del bulevar y soñar con Grecia mientras chupaba la miel que siempre llevara en un bote de latón en un bolsillo de su americano, acaso porque todo un enjambre de áticas abejas había reencarnado en el cuerpo rijoso y ultrasensible de aquel indio chorotega que tenía manos de marqués" (Sassone 1917: XIV-XV, XVIII).

${ }^{12}$ Se refiere al bienio iniciado en el 14 de abril de 1931 con la proclamación de la Segunda República Española, con el gobierno provisional formado por Manuel Azaña el 14 de octubre de ese año y con el gobierno con participación socialista que el mismo Azańa presidiría desde el 16 de diciembre de 1931 hasta el 12 de septiembre de 1933.
} 
y la persecución de las primeras horas, que vivió en una ciudad iluminada por las llamas e impregnada con el extraño olor de "miles y miles de cadáveres incinerados" (195), y en la mañana del 21 de julio decidió refugiarse con su mujer en el consulado del Perú, desde el cual sería evacuado el 11 de agosto. Después de varias semanas en un París que ya lo repugnaba, un "París todo erizado de puños en alto y todo hirviente de odio a la España verdadera" (233), viajó a su Lima natal, donde se dedicaría -amparado por la dictadura del general Óscar R. Benavides- a una fecunda actividad propagandística a favor de Franco. ${ }^{13} \mathrm{~A}$ comienzos de abril de 1939, Sassone festejó el triunfo del caudillo con un sonoro " $\mathrm{i}$ Arriba Espańa!”, publicado en la primera página de la revista El Mercurio Peruano (275), y en junio de ese ańo dio el último retoque a su libro al volver a pisar tierras españolas:

Yo he saludado con júbilo a mi Madrid al verle despierto de su pesadilla, todavía sudoroso del íncubo, haciéndose al gusto nuevo y maravilloso de su liberación. Porque yo le dejé bajo un cielo de plomo, negro de malas ideas, denso de pesadumbre y de vergüenza, cuando todavía gravitaba sobre él la muerte del inolvidable José Calvo Sotelo, asesinado por los cínicos que hablaban de lealtad y no fueron leales ni siquiera a sí mismos, y ahora vuelvo a encontrarle limpio de malos extranjeros, limpio también de malos españoles, con su cielo alegre profundo y azul, sembrado de almas por sus luceros luminosos y siento y sé que las estrellas son de carne heroica y cantan vencedoras, y yo no vi jamás un cielo como este. ¡Las estrellas están vivas! (286-287).

\section{LA VEJEZ DE LOS REVOLUCIONARIOS}

Ser joven y no ser revolucionario es una contradicción hasta biológica; pero ir avanzando en los caminos de la vida y mantenerse como revolucionario, en una sociedad burguesa, es dificil.

Salvador Allende

A mediados de los años treinta, y a pesar del paso de las décadas, otros de los antiguos modernistas aún mantenían vínculos -atenuados en algún caso, institucionalizados en otroscon sus aspiraciones revolucionarias de antaño, y desde una militancia parcial o totalmente

\footnotetext{
${ }^{13}$ Entre muchos artículos, conferencias y poemas proselitistas, destaca un soneto titulado "Banderas victoriosas", reproducido en su libro de memorias, que glosaba el himno de Falange Española y llevaba como epígrafe los versos "Volverán banderas victoriosas / al paso alegre de la paz": "España, de titanes manadero, / dos héroes nuevos con diverso sino: / el uno, cara al sol cayó supino, / y el otro cara al sol va con su acero. // Paso franco, pues Franco es el guerrero / que a España lleva a su imperial destino, / y desde el cielo alúmbrale el camino / José Antonio, de guardia en su lucero. // ¡Banderas victoriosas! Frase bella / que por el héroe muerto fue forjada; / el héroe vivo cumplirá con ella. // Así resurge España iluminada: / en el cielo, la lumbre de una estrella; / en la tierra, la lumbre de una espada" (Sassone 1939: 254-255).
} 
intacta expresaron su apoyo a la lucha de la República Española. Podría referirme aquí a los cantos a la Espańa republicana y a Lorca del dirigente socialista uruguayo Emilio Frugoni (1880-1969), miembro a comienzos de siglo de ese "modernismo ácrata y revolucionario" que era una "modalidad original del modernismo uruguayo" (Pereda Valdés 1960: 210); ${ }^{14}$ al poeta y ensayista panameño Guillermo Andreve (1879-1940), primer firmante y quizá redactor de un manifiesto de "intelectuales panameños de izquierda" a favor de la República que fue publicado en el diario Panamá-América el 6 de diciembre de 1937; $;^{15}$ al parnasiano ecuatoriano Francisco José Fálquez Ampuero (1877-1947), que respondió con euforia a un discurso del clérigo español y prorrepublicano Juan García Morales; ${ }^{16} \mathrm{o}$ al poeta boliviano Gregorio Reynolds (1882-1948), participante en un "Homenaje a Federico García Lorca" celebrado en La Paz el 12 de diciembre de 1936. ${ }^{17}$ En las siguientes páginas me limitaré a esbozar el posicionamiento de cuatro antiguos modernistas del Río de la Plata.

En su prólogo a Crónicas del Bulevar (1902), Rubén Darío presentaba a Manuel Ugarte (1875-1951) como un joven argentino poseído -"como toda la intelectualidad hispanoamericana desde hace unos quince años"- por el espíritu y el pensamiento parisinos, de los cuales había aprendido, sin embargo, no sólo la finura y la ironía, sino el amor a la acción y la fe en un mundo más justo. Relataba el nicaragüense que "hemos asistido juntos a reuniones socialistas y anarquistas", después de las cuales "mis ensueños

\footnotetext{
${ }^{14}$ Sobre la militancia prorrepublicana de Emilio Frugoni y sus poemas "A Federico García Lorca" -"Aquí me tienes, García Lorca, / con mi verso como un puñal"- y "Oda a España en el martirio", véase mi libro Uruguay y la guerra civil española (Binns 2016: 338-345).

${ }^{15}$ Aseveraba Andreve, en un artículo de comienzos de la guerra: "Los liberales de América, los socialistas de América, los hombres que ansían una nueva organización social, un reparto más equitativo de la riqueza, un nivel superior de cultura para las masas, una concepción más amplia de la justicia; el derecho, en fin, a la vida con igualdad de posibilidades para todos, deben ayudar espiritualmente a la Espańa liberal, haciendo votos por que alcance un triunfo transcendente y glorioso, que sea como la primera etapa en la jornada del desquite emprendida contra los métodos reaccionarios que amenazan al pensamiento humano, a la libertad humana, con una noche tan pavorosa como la de la Edad Media” (Andreve 1936: 3).

16 "Si en la guerra fratricida que nos ocupa se dan actos de supina crueldad; si la carnicería se prolonga con aspectos que recuerdan los tiempos de Atila y Gengiskán, la responsabilidad no es de los hombres libres y sensatos, de la porción mayoritaria democrática, sino de los reaccionarios, de los militares infatuados que combaten al pueblo, al poder que vive en su heroísmo y su derecho, sin reparar que 'el pueblo es Dios y contra Dios no pueden los cañones'. Pero lo más palpitante de verdad y sensación es la súplica que el tonsurado García Morales dirige al Papa. [...] Con soldados como los que rinden la vida bajo las banderas leales y con propagandistas tan profundamente sinceros como este sacerdote, la noble causa libertaria de España debe esperar el triunfo de sus ideales con fe y entereza" (cit. por Binns 2012a: 271).

17 "Por tu vida sin mancha, por tu vida / consagrada del todo a los pequeńos; / por tu obra que es sangre del costado / del Rabí Nazareno, / y por tu muerte sin motivo, / perdura en nuestras almas tu recuerdo: / vida, pasión y muerte / de Jesús Galileo. // En España, tu madre y madre nuestra, / se matan entre hermanos. Su denuedo / -ferocidad fanática- proviene / de las tinieblas del medioevo. / Igual que un escorpión junto a las brasas / es la energía del orgullo ibérico. // ¡Ah la locura militante / que azuza el frenesí de los guerreros!” (Reynolds 1937: 36-37).
} 
libertarios se han encontrado un tanto aminorados" a raíz de "la irrupción de la grosería, de la testaruda estupidez, de la fealdad, en un recinto de ideas", mientras que "Ugarte, convencido, apostólico, no ha dejado de excusarme esos excesos, y se ha puesto hasta de parte del populacho que no razona, y me ha hablado de próxima regeneración, de universal luz futura, de paz y trabajo para todos, de igualdad absoluta, de tantos sueńos..." (Ugarte 1902: I, IV-V). El argentino, inspirado por las figuras de Émile Zola y Jean Jaurés, terminaría polemizando con Darío en su defensa de un arte social, y se haría conocido como uno de los grandes portavoces de un arielismo antiestadounidense, a partir de El porvenir de la América española (1910), y como un socialista díscolo pero prestigioso, interlocutor de varios de los grandes pensadores hispanoamericanos de los años veinte y treinta: José Carlos Mariátegui y Víctor Haya de la Torre, José Vasconcelos y Augusto Sandino.

Después de décadas en Europa, Ugarte regresó a Argentina en julio de 1935 y volvió a afiliarse al Partido Socialista, pero no llegó a entenderse ni con los dirigentes del Partido ni con los intelectuales argentinos que se reunían en el frente antifascista de la AIAPE (Agrupación de Intelectuales, Artistas, Periodistas y Escritores). En octubre de 1936 fundó en Buenos Aires la revista Vida de Hoy, desde cuyas páginas contempló la llegada de Gregorio Marañón con escepticismo nacionalista (afín al de Lugones, pero desde otro prisma) - "la Argentina es una nación que tiene sus propias preocupaciones y no puede prestarse a servir de ring para la lucha de ajenos extremismos"-, criticó a intelectuales españoles como Ortega y Gasset que abandonaban su país e intentaban no tomar partido, y publicó las respuestas de decenas de intelectuales a una encuesta que él mismo formulaba -sin tomar partido: no era suya la guerra- bajo el título "¿Qué piensa usted de la situación actual de España?" (Binns 2012b: 775-776).

Alberto Ghiraldo (1875-1946), un escritor a caballo "entre el rubenismo estético y la militancia libertaria", divulgó su pensamiento anarquista desde revistas y periódicos como el primer Martín Fierro (1904), El Sol (1898-1903) e Ideas y figuras (1908-16), y en libros como Música prohibida (1904) y Triunfos nuevos (1910), en un deslizamiento que lo llevaba "desde París entendido como máxima condensación de la torre de marfil, hacia el emblema simbolizado en el penal de Ushuaia. Quizás entre la bohemia de exaltación individualista y marginal, y la militancia que intentaba rescatar lo comunitario y la responsabilidad social" (Viñas 2004: 216-217). La primera parte de la ecuación podría trazarse desde el breve prólogo escrito por Rubén Darío para su poemario Fibras (1895) hasta las Obras completas del nicaragüense que el propio Ghiraldo publicó en Madrid, en veintidós tomos, entre 1917 y 1919, o la sucesión de ediciones posteriores de las cuales también se encargó. La parte segunda se plasma en una estrofa -citada por Vińas (219)- del poema "Chicago", que publicó Ghiraldo en Ideas y figuras para la fiesta del Primero de Mayo de 1916: “iTodos de pie! ¡A la lucha! ¡Ni Dios, ni ley, ni patria! / ¡Cada hombre sea un ejército; nadie obedezca a nadie! / ¡Ni altares, ni sanciones, ni banderas! / ¡No encuentren los esclavos dónde atarse!”.

Después de vivir en Espańa entre 1916 y 1934, y de un intento frustrado de establecerse en La Plata, Ghiraldo se trasladó en 1935 a Chile, donde se dedicó a escribir insistentemente-poesía, ensayos, poemas en prosa-sobre la guerra española. Con su espíritu 
libertario en pleno funcionamiento, dedicó una columna semanal a la contienda en España Nueva (1936-1939), un legendario periódico republicano fundado en España por Rodrigo Soriano (1906-1924) y que fue revivido en Santiago de Chile -donde Soriano era embajador de la República- desde el 21 de noviembre de 1936 hasta finales de la guerra (Barchino y Cano Reyes 2013: 39). En esa columna, aparte de las reflexiones de Ghiraldo sobre el conflicto, destaca su inclusión periódica de un "Cancionero libertario", con poemas rescatados del pasado -algunos, como "Los pistoleros de Barcelona" (15 de mayo de 1937), resignificados en el nuevo contexto-y otros surgidos de la contingencia, como "Día de gloria":

Un día, que ha de quedar fijado para siempre en un libro inmortal, un pueblo dijo ¡nunca! a los tiranos que querían uncirlo a su dogal.

Desde entonces hay más luz sobre la tierra, hay más dolor también sobre el dolor. ¡Se arrojaron al crimen de la guerra los cristianos sin Cristo y sin amor! [...]

Un día, que eternamente grabará la historia, sin duda llegará en que habrán de romperse las cadenas.

¡El prodigio será! ¡El mal vencido, se hundirá en las sombras y España de las sombras surgirá! (Ghiraldo 1938: 2).

Cuando Alejandro Sux (1888-1959) llegó a París en 1910, deportado por su activismo anarquista, llevaba bajo el brazo una reciente novela autobiográfica, titulada Bohemia revolucionaria. Jesús Cano Reyes, en un estudio iluminador sobre los corresponsales hispanoamericanos en la guerra civil espańola, ha recordado el fulgurante encuentro que tuvo Sux con Darío, que le brindó su amistad, lo convirtió en una especie de secretario, prologó su libro La juventud intelectual de la América Hispana (1911), se enorgulleció de las melenas e indumentaria extravagantes de su joven discípulo, y -en palabras del propio argentino- "me exhibía como ejemplar zoológico raro y me presentaba haciendo grandes elogios literarios, pero agregando invariablemente: 'Sux es el Alcalde Honorario del barrio de los apaches"' (Cano Reyes 2017: 171).

En la época de la guerra española, Sux vivía de nuevo en la capital francesa, desde la cual enviaba al diario de Buenos Aires El Mundo sus frecuentes "Cartas de París". Al oír las noticias de la llegada del general Mola y su ejército a las afueras de Irún, en la segunda 
semana de agosto de 1936, Sux se trasladó con una caterva de aspirantes a corresponsales a la orilla norte del río Bidasoa para observar con prismáticos el conflicto, codearse con los refugiados que llegaron a Hendaya en barco o corriendo agachados por el puente, y darse cuenta de la desorganización y la improvisación de los republicanos. Entre el 11 de agosto y el 5 de septiembre -fecha de la caída de Irún-, envió a su diario crónicas fascinantes sobre la lucha por la ciudad y los preparativos para la defensa de San Sebastián. En el último de esos envíos, resumiría la experiencia de manera muy gráfica:

Yo he sido espectador de primera butaca, y he penetrado en los entretelones, camarines y bambalinas del escenario irunés; también he presenciado de cerca la comedia siniestra de la neutralidad tras las barreras de la frontera, y conocido personalmente a los agentes rebeldes que se informaban ante los miembros del Frente Popular para comunicarlo a los jefes de los comités carlistas, falangistas, monárquicos, etc., etc., que tienen sede en San Juan de Luz y en Bayona, en Biarritz y en Hendaya (cit. por Binns 2012b: 754).

Durante las semanas siguientes, Sux relataría cómo aprovechó la noche para cruzar clandestinamente en un barco pesquero de Saint Jean de Luz a la ciudad asediada de Bilbao (Sux 1936a: 2), y en otra oportunidad cómo viajó a Pamplona para entrevistarse fugazmente con el propio Mola (1936b: 3). La acción bélica iba, sin embargo, alejándose cada vez más de la frontera, así que Sux regresó a París, y desde allí y desde otras ciudades del norte seguiría comentando la guerra durante los ańos siguientes, para denunciar la presencia italiana y alemana en las Islas Baleares (1937a: 6), para desenmascarar la frivolidad de intelectuales supuestamente comprometidos con España (1937b: 3), para reflexionar sobre el abuso del concepto de nacionalismo por parte de Franco - ¿Es que el general Franco ignora el Diccionario de la Lengua Castellana?”- (1937c: 3), para relatar la fascinación por la guerra espańola en Bruselas (1938a: 3), y para darse cuenta -en "Las lecciones militares de la guerra española" - de que la guerra de España era "un ensayo general de las futuras [guerras]; se ensayan las armas, los métodos, los sistemas... iPobre España!” (1938b: 3).

Horacio Quiroga (1878-1937) tuvo una larga travesía por el modernismo, dominada por un morbo -preñado de decadentismo en Los arrecifes de coral (1901) y El crimen del otro (1904) - que nunca lo abandonaría en sus grandes obras posteriores, y pasó también por esa bohemia revolucionaria relatada por Sux. Ángel J. Cappelletti, en su historia del anarquismo latinoamericano, detectaba en sus cuentos "un soplo de rebeldía y de inconformismo, que nos hace pensar, a veces, en los relatos de otro genial simpatizante del anarquismo, Joseph Conrad" y recordaba que "Quiroga estuvo en contacto, en su temprana juventud, con círculos anarquistas montevideanos, tuvo una fugaz militancia en dichos grupos, pero antes de llegar a la madurez se desentendió de la ideología libertaria, sin llegar a repudiarla" (1990: 73).

No llegó, en efecto, a repudiarla, como se percibe en la correspondencia con su amigo Ezequiel Martínez Estrada de sus últimos años, donde dejó muy claro, por otra parte, su rechazo al comunismo y a la política de frente popular que éste aspiraba a liderar, 
y reclamaba para sí -con algo de autoironía, quizá- un espíritu anarquista indomable. En una carta del 13 de julio de 1936, comentó a su amigo argentino por qué había rechazado una invitación para que contribuyera a "cierta revista de izquierda", explicando con dolor y con un "gran desengaño" los recelos que había percibido en sus propios peones y las burlas y acusaciones que estos le hacían al verlo trabajar junto a ellos con una azada o un pico, como si él no tuviera derecho a trabajar también y como si al hacerlo les robara. Esta actitud provenía, aseguró Quiroga, del "negocio moral comunista. Negocio con el dogma de Stalin, negocio Blum, negocio Córdova Iturburu”. ${ }^{18}$ En esas circunstancias, no había tenido más remedio que negarse a la invitación: "Como bien ve, un solitario y valeroso anarquista no puede escribir para la cuenta de Stalin y Cía” (Martínez Estrada 1995: 138-139).

Pocos meses más tarde, en febrero de 1937, Quiroga se suicidaría, pero en sus últimos meses de vida, y con ese espíritu de "solitario y valeroso anarquista" intacto, no podía dejar de entusiasmarse ante las noticias que llegaban de España. Así lo expresó, intercalando una breve digresión en su carta a Martínez Estrada del 19 de agosto de 1936:

España. - Me interesa muchísimo. Por encima de las mezquindades y sangrienta rebusca de privilegios que incuban en todo aquello, hay algo innegable que me arrastra. Y ello es que de un lado está la buena causa, y del otro, la mala. Cuando las papas queman, un liberal es ya un compañero. No quiero nada de militares, mi grande fobia, y tampoco de curas. Luego las muchachas esas, apasionadas a tal punto. ¿Ve Vd. bien en el campo de fuego unas cuantas mujeres tendidas muertas a balazos y bayonetazos por hombres? ¡Mujeres, sin mayores fuerzas, agujereadas como hombres en un campo de batalla! Me angustia esto -o me angustió en el momento en que lo vi claro (160).

\section{Colofón. Militancia desde el más allá}

No han muerto! Están en medio de la pólvora, de pie, como mechas ardiendo.

Pablo Neruda

La guerra civil española encendió los ánimos de los intelectuales de Hispanoamérica, que la leyeron y la vieron en imágenes que cubrían las portadas de los periódicos, llenaban las revistas ilustradas, empapelaban las paredes en carteles propagandísticos y dejaban

\footnotetext{
${ }^{18}$ Resulta curiosa la combinación de nombres. El socialista Léon Blum era presidente del gobierno del Frente Popular francés desde el mes anterior (5 de junio de 1936); el poeta, ensayista y crítico de arte argentino Cayetano Córdova Iturburu, militante comunista, era uno de los intelectuales más influyentes de la AIAPE, viajaría a la España en guerra en febrero de 1937 y publicaría en 1938 el libro España bajo el comando del pueblo (véase Cano Reyes 2017: 302-306).
} 
boquiabiertos a los espectadores de los noticiarios en los cinematógrafos. Era la primera guerra mediática de la historia, la primera guerra en que se bombardeaba sistemáticamente a la población civil, y era España -esa misma madre España que tanto repudio y tanta pasión había suscitado entre los modernistas- quien la padecía.

La llamada de la guerra llegó no sólo a las lejanas retaguardias de cada país de Occidente. Alcanzó hasta a los muertos. Manuel González Prada (1844-1918), pionero del anarquismo en el Perú y autor de libros de exquisito modernismo en Minúsculas (1901) y Exóticas (1911), revivió en la España en guerra con la publicación de la colección de ensayos Anarquía, publicada en 1938 en la editorial barcelonesa Tierra y Libertad.

Igualmente presente estaba José Martí (1853-1895), a través de militantes de la Cuba revolucionaria que habían derrocado años antes a Gerardo Machado pero ya vivían, desde el agotamiento popular, la nueva tiranía, surgida a la sombra de una sucesión de presidentes títeres, del coronel Fulgencio Batista. A falta de una revolución en Cuba, encontraban otra en España y para comprenderla recurrían, ¿cómo no?, a su Libertador. En palabras de Raúl Roa: si viviera Martí, luchador contra el "pretorianismo colonial" y las "camarillas monárquicas y oscurantistas" de su época, "estaría hoy, también, alentando con su verbo fúlgido y acaso con su presencia iluminada, a los españoles que han entablado duelo a muerte contra las mismas clases y fuerzas históricas que nos sojuzgaron y exprimieron, en nombre de Dios y de la civilización, durante más de cuatrocientos ańos" (Roa 1937: 24). Ahora bien, si las fuerzas franquistas se equiparaban con la España enemiga de Martí, las de la República correspondían a la otra España que quiso y que él mismo encarnaba. La Hispanidad no pertenecía a Ramiro de Maeztu y sus discípulos, sino al espíritu de Martí y de Dolores Ibárruri, La Pasionaria. Así lo aseveraban Juan Marinello, Ángel I. Augier y Carlos Rafael Rodríguez en su prólogo a un libro de Emilio Roig de Leuchsenring, titulado precisamente La España de Martí (1938):

Nada ofrece mejor prueba de la calidad genial del Libertador que esta pasión española hecha de amor y de dolor, más vigente ahora que cuando se expresó de modo insuperado. La España de Martí, la España-pueblo que le venía en la sangre es esta de ahora, la de Madrid y Guadalajara, limpiándose en el más ejemplar de los sacrificios de los retrasos empedernidos que Martí señaló y combatió con ardor espańolísimo. Por eso este libro, cubano como el que más, traspasa los límites isleños y al tocar la mejor hispanidad -la de Martí y Pasionaria-, toca lo humano. Ninguno más abarcador de nuestro propósito. Ninguno tan nuestro, tan hispánico y tan universal (cit. por Binns, Cano Reyes y Casado Fernández 2015: 693).

Desde su tumba en la catedral de León, Rubén Darío (1867-1916) fue obligado también a levantarse y a luchar en la guerra española. De Maeztu ya lo había alistado entre los suyos, ensalzándolo, en un libro de 1934 que tuvo un enorme peso en la ideología franquista, Defensa de la Hispanidad, como la figura que permitió una superación del sentimiento antiespañol que había dominado en las antiguas colonias a lo largo del siglo 
XIX: "Sólo por un milagro podían [los hispanoamericanos] volver los ojos con afecto hacia la madre patria. Ese milagro se llamó Rubén”. En efecto, el que era hasta 1898 "el más antiespañol de los escritores de América" -el poeta del "galicismo mental" que dijera Juan Valera- reinstituyó Espańa en el mapa intelectual de las Américas con ese puñado de poemas de sus Cantos de vida y esperanza, y notablemente con su "Salutación del optimista", que era -según de Maeztu- el "único himno hispanoamericano que tenemos":

Si un instinto de salvación nos quisiera mover a preparar el espíritu de las nuevas generaciones para la defensa de las tierras hispánicas, no habría ceremonial en que no se recitaran las mágicas estrofas:

¡Ínclitas razas ubérrimas, sangre de Hispania fecunda, espíritus fraternos, luminosas almas, salve!

El tema de la defensa de la Hispanidad llena el alma del poeta aquellos ańos (Maeztu 2001: 217-220).

En la Nicaragua de los años treinta, que tenía la peculiaridad de ser el único país americano en que la intelectualidad se posicionó mayoritariamente a la derecha, agrupándose en torno a la figura magistral del poeta granadino José Coronel Urtecho, los jóvenes Pablo Antonio Cuadra, Joaquín Pasos y Luis Alberto Cabrales fueron ardorosos defensores de la cruzada franquista. El primero de ellos era el discípulo hispanoamericano predilecto de Ramiro de Maeztu, ya había publicado textos en la revista de su maestro, Acción Española, y fue de los primeros intelectuales hispanoamericanos en visitar España en los meses posteriores a la guerra. Leal en su reconocimiento al maestro muerto, terminaría su folleto La Hispanidad y los anhelos de América con una cita de ese único himno hispanoamericano, la "Salutación del optimista”. "¿Dónde hay un horizonte que no sea negro en el mundo sino en la Hispanidad?", preguntaba Cuadra; "en medio de esta catástrofe, ¿dónde hay una fuerza que pueda de nuevo orientar al mundo?”. Únicamente en Espańa, se respondió, ya que España era mucho más que un solo país: poseía "veinte pueblos en un continente y un gran pueblo en el otro, católicos, llenos de fe y de ideales que le pueden dar fuerzas para dominar". Además, lo que estaba en juego no era sólo el futuro de América, sino el del mundo entero:

Necesitamos que [España] vuelva a dominar al mundo, necesitamos de nuevo ese Imperio, esa Cultura, esa Fe, para poder dirigir los destinos de la Historia Universal, que es la misión de la Hispanidad.

Y sobre esta verdad, que es la de salvar al mundo, necesitamos comunicarnos, unirnos, alentarnos, oír, en una palabra, la voz de aquel gran poeta, también nicaragüense, nuestro Profeta Rubén: 
Únanse, brillen, secúndense tantos vigores dispersos;

Formen todos un solo haz de energía ecuménica.

Sangre de Hispania fecunda, sólidas, ínclitas razas... (Cuadra 1939: 6).

Como muestra de esta reapropiación de la figura y obra de Darío en el marco de la Hispanidad, quisiera clausurar este estudio destacando la reescritura de otro de los Cantos de vida y esperanza por parte de Raúl A. Entraigas, un historiador, sacerdote salesiano y poeta ocasional de Río Negro, en la Patagonia argentina. Su poema "La marcha triunfal (Glosando a Rubén)" reproduce el ritmo de los anfíbracos de la "Marcha triunfal" de Darío, se inicia con el mismo verso - “YYa viene el cortejo!”- y va dialogando con el original, transformando por ejemplo el verso "Ya pasa debajo los arcos ornados de blancas Minervas y Martes" -tan arquetípicamente dariano en su ornamentalismo grecolatino- en otro que incorporaba la imagen, muy divulgada durante la guerra civil, de uno de los arcos de entrada a la Plaza Mayor madrileńa bajo una pancarta que rezaba “iNo Pasarán!”. Dice Entraigas: "Ya pasan debajo los arcos que forman los 'no pasarán'. / Jamás se habrán visto unos arcos triunfales como esos. ¡Jamás se verán!". 


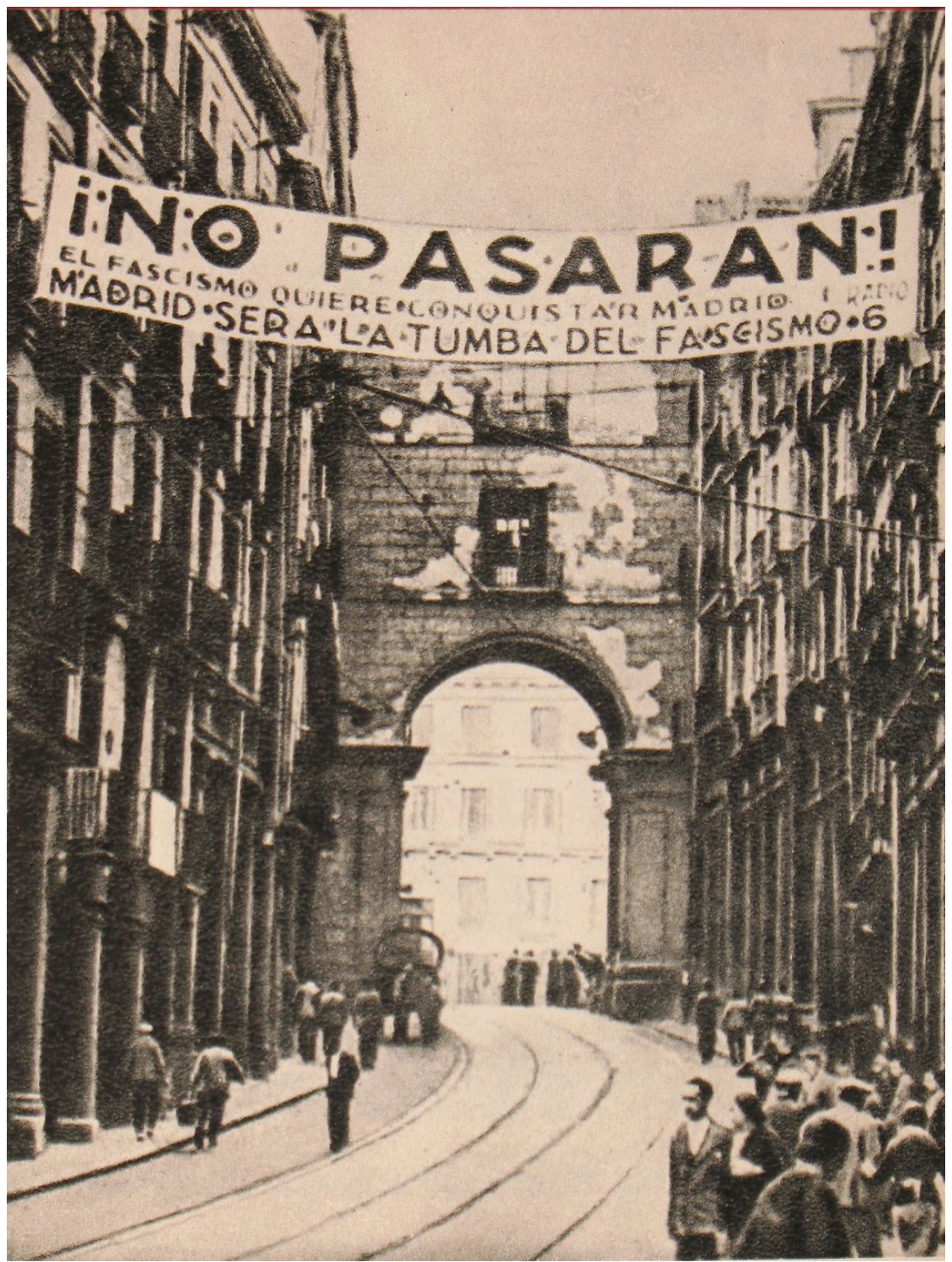

Fig. 2. "No pasarán”. Fuente: Wikimedia Commons 
El poema de Entraigas, fechado en Viedma el 20 de noviembre de 1936 -sin saber, probablemente, que era el día de la muerte de José Antonio Primo de Rivera; sin saber, evidentemente, que en ese mismo día, treinta y nueve años más tarde, moriría tras una prolongada agonía el generalísimo Francisco Franco-, enumera en un pequeńo catálogo de héroes (sin mencionar, curiosamente, ni a Primo de Rivera ni a Franco) a tres oficiales responsables del ataque que se estaba llevando a cabo en esos mismos días contra Madrid: al general José Enrique Varela, al coronel Juan Yagüe y al teniente coronel Heli Rolando de Tella. Incorpora, a la vez, un recuerdo caluroso del "gran mártir Sotelo", el monárquico y simpatizante fascista José Calvo Sotelo que había muerto asesinado cinco días antes del comienzo de la guerra civil. El homenaje más encendido se dedica, sin embargo, al general Emilio Mola, cuyos intentos de tomar Madrid desde el norte habían fracasado, pero que resultaba particularmente interesante para Entraigas porque era "indiano": había nacido en 1887 en el territorio todavía español de Cuba, donde viviría hasta los once años, cuando la pérdida de la colonia llevara a su familia a trasladarse a la Península. Habría que leer estos versos dedicados a Mola como si fueran -así lo habría querido Entraigas, así Cuadra y los demás defensores americanos de la Hispanidad- la voz o el espíritu del propio Darío encareciendo con sus hipérboles rítmicas el triunfo anticipado de las huestes de Franco:

¡Ya pasa el gran Mola! ¡Con él, las Américas!

¡Ya pasa el gran Mola, pesado de ideales

$Y$ empresas que son tropicales

Y prenden y cuajan en tierras ibéricas!

¡Ya viene el indiano

Llevando en su mano

Gloriosa, la enseña que ondea engreída!

La simbólica enseña perdida

Se ha encontrado en el alma española

$\mathrm{Y}$ es dos veces gloriosa en las manos de Mola (Entraigas 1936: 3).

\section{ObRas CitADAS}

ABC. 1936. "Adhesión de intelectuales". Madrid, 31 de julio: 30.

Amorós, Mario. 2008. Compañero presidente. Salvador Allende, una vida por la democracia y el socialismo. Valencia: Universitat de València.

Andreve, Guillermo. 1936. "En el crisol". Estrella de Panamá, Panamá, 30 de julio: 3.

Barchino, Matías y Jesús Cano Reyes, eds. 2013. Chile y la guerra civil española. La voz de los intelectuales. Madrid: Calambur.

Binns, Niall. 2011. “¿El 'sabio' o el 'traidor’? Gregorio Marañón entre los intelectuales de Uruguay (Montevideo, 1937)”. Revista de Filología Románica, Madrid, Anejo viI: 69-76. 
- - -, ed. 2012a. Ecuador y la guerra civil española. La voz de los intelectuales. Madrid: Calambur.

- - , ed. 2012b. Argentina y la guerra civil española. La voz de los intelectuales. Madrid: Calambur.

- - -, ed. 2016. Uruguay y la guerra civil española. La voz de los intelectuales. Barcelona: Calambur.

Binns, Niall, Jesús Cano Reyes y Ana Casado Fernández, eds. 2015. Uruguay y la guerra civil española. La voz de los intelectuales. Madrid: Calambur.

Borges, Jorge Luis. 1968. "Mensaje en honor a Rubén Darío". Ernesto Mejía Sánchez, ed., Estudios sobre Rubén Dario. Ed. Ernesto Mejía Sánchez. México: FCE. 13.

- - -, 1997. "Ultraísmo". Textos recobrados, 1919-1929. Ed. Sara Luisa del Carril. Barcelona, Emecé. 126-131.

Cano Reyes, Jesús. 2017. La imaginación incendiada. Corresponsales hispanoamericanos en la Guerra Civil Española. Barcelona: Calambur.

Cappelletti, Ángel J. 1990. “Anarquismo latinoamericano”. Carlos M. Rama y Ángel J. Cappelletti, sel. y notas, El anarquismo en América Latina. Caracas: Ayacucho. IX-CCXvI.

Casal Castel, Alberto. 1937. "Diez horas con Gregorio Marañón”. El Hogar, Buenos Aires, 16 de abril: 12,31 .

Claridad. 1936. "Fúnebre lista". Popayán (Colombia), 26 de noviembre: 3.

- - -, 1939. "Ayer y hoy". 13 de abril: 3.

Croce, Marcela. 2001. "Buenos Aires, capital del anarquismo". Fin de siglo y modernismo. Ed. María Payeras Grau y Luis Miguel Fernández Ripollo. Palma: Universitat de les Illes Balears. 531-536.

Cuadra, Pablo Antonio. 1939. La Hispanidad y los anhelos de América (conferencia pronunciada el día 4 de octubre de 1939). Valencia: Ediciones Prensa y Propaganda.

El Hogar. 1937. "Marañón a borde del 'Buen Aire', Buenos Aires, xxxıII: 1435, 16 de abril: 40.

El Liberal. 1939. Editorial. Bogotá, 3 de abril: 5.

El Siglo. 1939. "El pensamiento colombiano y el triunfo del Generalísimo Franco". 2 de abril: 13 .

Entraigas, Raúl A. 1936. "La marcha triunfal (Glosando a Rubén)". Patria Española. Bahía Blanca (Argentina), 28 de noviembre. 3.

Finchelstein, Federico. 2008. La Argentina fascista. Los origenes ideológicos de la dictadura. Buenos Aires: Sudamericana.

Franzé, Javier. 1997. "Lugones, 1897: socialismo y modernismo". Cuadernos Hispanoamericanos, Madrid, 560: 63-78.

Ghiraldo, Alberto. "Día de gloria". España Nueva, Santiago de Chile, II: 60: 2.

Gracia, Jordi. 2004. La resistencia silenciosa. Fascismo y cultura en España. Barcelona: Anagrama.

Gutiérrez Girardot, Rafael. 1983. Modernismo. Barcelona: Montesinos.

Henríquez Ureña, Max. 1962. Breve historia del modernismo. México: FCE. $2^{a}$ ed. 
Hernández García, José Ángel. 2006. La guerra civil española y Colombia. Bogotá: Universidad de La Sabana/Editorial Carrera 7a .

Lugones, Leopoldo. 1897. Las montañas del oro. Buenos Aires: Imp. Jorge A. Korn.

- - -, 1931. La patria fuerte. Buenos Aires: Círculo Militar, Biblioteca del Oficial.

Maeztu, Ramiro de. 2001. Defensa de la Hispanidad. Madrid: Rialp. 2a ed.

Mapes, E.K. 1938. Escritos inéditos de Rubén Dario. Nueva York: Instituto de las Españas.

Martínez Estrada, Ezequiel. 1995. El hermano Quiroga. Cartas de Quiroga a Martínez Estrada. Caracas: Ayacucho.

Muñoz Carrasco, Olga, ed. 2013. Perú y la guerra civil española. La voz de los intelectuales. Madrid: Calambur.

Pacheco, José Emilio. 1999. "Introducción”. Antología del modernismo, 1884-1921. México: Era. $3^{\mathrm{a}}$ ed. XI-LIV.

Pereda Valdés, Ildefonso. 1960. “El modernismo en el Uruguay”. Letras, Curitiba (Brasil), 11: 204-214.

Rama, Ángel. 1970. Rubén Darío y el modernismo: circunstancia socioeconómica de un arte americano. Caracas: Universidad Central de Venezuela.

Reynolds, Gregorio. 1937. "A la memoria de Federico García Lorca”. Peña de Escritores y Artistas, Homenaje a Federico García Lorca. La Paz: Editorial Arnó. 35-41.

Rock, David. 1993. La Argentina autoritaria. Los nacionalistas, su historia y su influencia en la vida política. Buenos Aires: Ariel.

Salvador, Álvaro. 1986. Rubén Dario y la moral estética. Granada: Universidad de Granada.

Sassone, Felipe. 1917. La canción del bohemio y otros poemas. Madrid: V. H. de Sanz Calleja.

- - , 1939. España, madre nuestra. Notas autobiográficas. Madrid: Ediciones Españolas.

Sux, Alejandro. 1936a. "Una visita a Bilbao". El Mundo, Buenos Aires, 6 de octubre: 2.

- - -, 1936b. "Normalidad y orden en Pamplona; dos minutos de charla con el General Mola”. El Mundo, 10 de octubre: 3.

- - -, 1937a. "Las Islas Baleares". El Mundo, 23 de enero: 6.

- - -, 1937b. "2do. Congreso Internacional de Escritores”. El Mundo, 6 de agosto: 3.

- - -, 1937c. "Nacionalismos". El Mundo, 22 de noviembre: 3.

- - -, 1938a. "Sangre española". El Mundo, 13 de enero: 3.

- - -, 1938b. "Las lecciones militares de la guerra espańola”. El Mundo, 14 de junio: 3.

Trapiello, Andrés. 2010. Las armas y las letras. Literatura y guerra civil (1936-1939). Barcelona: Destino. $3^{\mathrm{a}} \mathrm{ed}$.

Ugarte, Manuel. Crónicas del Bulevar. Prólogo de Rubén Darío. París: Garnier Hermanos.

Valencia, Guillermo. 1936a. "Disidencia, no!”. Claridad, Popayán, Colombia, 8 de agosto: 3.

- - -, 1936b. "Contra los bárbaros”. Claridad, Popayán, 10 de septiembre: 3-4.

- - -, 1937. "El Capitán Luis Crespo Guzmán”. Claridad, Popayán, 21 de enero: 3.

- - -, 1939. “Arriba España!”. Claridad, Popayán, 30 de marzo de 1939: 3.

- - -, 1955. Obras poéticas completas. Madrid: Aguilar.

Viñas, David. 2004. Anarquistas en América Latina. Buenos Aires: Paradiso.

Yunque, Álvaro. 1937. "Poetas tiranófilos”. Unidad. Buenos Aires, II: 2, septiembre: 9. 